\title{
Chronology of Marx's Works
}

The works below are listed in chronological order according to the date of first publication or of composition if not published in Marx's lifetime; the latter dates appear in square brackets. With the exception of the Grundrisse and the volumes of Capital, Marx's works are cited throughout the text by these dates and the abbreviations listed in the Note on Abbreviations, Citations, and Translations: (Marx [1844] EW: 276).

The list is interrupted twice by what I consider to be a significant turning point of particular personal, scientific, and political importance to Marx, thus dividing his lifework into three distinct phases. These events should not simply be treated as breaks in Marx's career, but rather as "biographemes" that illuminate the work in the life and the life in the work (cf. Barthes 1978 [1954], 1989).

[1840-41] The Difference Between the Democritean and the Epicurean Philosophies of Nature (doctoral dissertation)

[1842] Excerpts on the History of Art and Religion (Bonner Hefte)

1842 Debates on the Law on Thefts of Wood

1843 On the Jewish Question

1843-44 A Contribution to the Critique of Hegel's Philosophy of Right: Introduction

[1844a] Excerpts from James Mill's "Elements of Political Economy"

[1844b] Economic and Philosophical Manuscripts of 1844 
1845 The Holy Family, or Critique of Critical Criticism (with Friedrich Engels)

[1845] Theses on Feuerbach

[1845-47] The German Ideology (with Friedrich Engels)

1847a The Poverty of Philosophy, Answer to the Philosophy of Poverty by M. Proudhon

1847b Wage Labor and Capital

1848 The Communist Manifesto (with Friedrich Engels)

In 1850, after emigrating to London, Marx resumes his economic studies in the British Museum. Engels moves to Manchester to manage the firm Ermen and Engels.

1850 The Class Struggles in France: 1848-1850

1852a The Eighteenth Brumaire of Louis Bonaparte

$1852 \mathrm{~b}$ The Great Men of the Exile

1853a Revelations Concerning the Communist Trial in Cologne

1853b Lord Palmerston

$1854 \quad$ Revolutionary Spain

1856a Revelations of the Diplomatic History of the Eighteenth Century

$1856 \mathrm{~b}$ Speech at the Anniversary of the "People's Paper"

[1857-58] Grundrisse

1857-62 Articles for the "New York Cyclopaedia"

1859 Contribution to the Critique of Political Economy

$1860 \quad$ Herr Vogt

[1861-63] Theories of Surplus Value

[1862] Results of the Immediate Process of Production (unpublished chapter 7 of Capital, vol. 1)

In 1864 Marx and Engels participate in the founding of the (First) International Working Men's Association.

[1864-67a] Capital. Vol. 3, The Process of Capitalist Production as a Whole (added revisions in 1870s)

[1864-67b] Capital. Vol. 2, The Process of Circulation of Capital

1865 Wages, Price, and Profit

1867 Capital. Vol. 1, The Critique of Political Economy (added revisions in 1870s) 
xviii Chronology of Marx's Works

$\begin{array}{ll}1871 & \text { The Civil War in France } \\ 1875 & \begin{array}{l}\text { Critique of the Gotha Programme } \\ {[1879-83]}\end{array} \\ \text { The Ethnological Notebooks of Karl Marx } \\ {[1881 \mathrm{a}]} & \begin{array}{l}\text { Marginal Notes on Adolph Wagner's "Lehrbuch der politischen } \\ \text { Oekonomie" }\end{array} \\ {[1881 \mathrm{~b}]} & \text { The Mathematical Notebooks of Karl Marx }\end{array}$




\section{Reading Marx Writing \\ Melodrama, the Market, and the "Grundrisse"}


